\title{
Article
}

\section{De Kretser's Retelling of a Ghost Love Story}

\author{
Alejandra Moreno-Álvarez@ \\ Department of English, French and German Studies, University of Oviedo, 33011 Oviedo, Spain; \\ morenoalejandra@uniovi.es
}

Received: 8 July 2020; Accepted: 14 August 2020; Published: 19 August 2020

check for updates

\begin{abstract}
Australian author Michelle de Kretser addresses in her literary work ideas of home and belonging. In Springtime. A Ghost Story (2014) the author gives voice to an ambiguous and variable subject who coexists with her past, present and future, inhabiting a fluid trans-space where love has a principal role. Frances, the main character in Springtime, sees ghosts who unconsciously allow her to voice her insecurities and doubts concerning her life existence. These phantoms contribute to the formation of Frances' alternative conceptualization of subjectivity. At the same time, de Kretser offers in this dystopic novella a much-needed escape from binary definitions of inclusion/exclusion, offering palimpsests of the spaces that Frances inhabits-Melbourne, Sydney and Paris. This main character is a fluid flâneuse who tries to adjust to her glocality constituted and reconstituted by a discursive imaginary. In this article, I analyze how de Kretser subverts ghost story patterns, destabilizes binary thinking, and decentralizes the human subject offering the reader an alternative haunting love story with an open ending, where cities, ghosts, humans, dogs and nature become active characters who are-in-this-together-but-who-are-not-one-and-the-same.
\end{abstract}

Keywords: ghosts; love; dystopia; glocality; inbetweenness; flâneuse

\section{Introduction}

Within the current dystopian scenarios, questions of home, belonging and love are central to discourses due to mass transnational movements taking place worldwide. The latter disrupts the binary pattern western discourses have been constructed upon. In Springtime. A Ghost Story ${ }^{1}$ (de Kretser 2014), Australian author Michelle de Kretser, born in Sri Lanka, focuses precisely on these matters, attempting to offer alternative identarian formations with the aid of ghosts. At the same time, the author centralizes the Vitruvian subject whom Julienne van Loon describes as "'an ideal of bodily perfection' which doubles up as a set of values that are embedded in our language, in the way we think, and in the social and ideological studies and institutions we inhabit" (Van Loon 2019). In Questions of Travel (2012) de Kretser clearly draws the I/Other dichotomy and uses the 2004 tsunami as a fictitious literary dystopic trope to erase the constructed western binary thinking. She projects, with an apocalyptic ending, a desirable utopic new beginning where, wishfully, no dichotomies will take place. However, readers are given the possibility of imagining a future where, unfortunately, the human subject is still at the center. In Springtime, the author employs, instead, a haunting trope to give voice to a subject who coexists with her insecurities. Frances, the main character in Springtime, meets Charlie, who was then married and had a young son, at a party in Melbourne. They both move to Sydney with her dog, Rod. It is in Sydney, where everything seems alien and unfamiliar, where Frances sees ghosts who will unconsciously allow her to voice her self-doubts, to revisit her past and to take decisions in the present which will affect her future. These phantoms aid Frances to understand where her self-doubts

\footnotetext{
1 From now on, Springtime.
} 
come from and to reconstruct her subjectivity. de Kretser not only gives voice to Frances, but also to her dog, Rod, to the ghost dog, Hector, to the ghost mannequin, Sybil, and to the cities of Melbourne, Sydney and Paris. In Springtime, the author offers the much-needed escape from binary definitions and offers spaces to inhabit, where cities, ghosts, humans and nature are all crucial since, as Rosi Braidotti underlines, "we-are-in-this-together-but-we-are-not-one-and-the-same" (Braidotti 2017, p. 47). Frances becomes aware that she is "intertwined with the totality of things-including zoe/geo/techno 'things"" (Braidotti 2017, p. 47). She is in the process of becoming not-One, that is, "a complex multiplicity held together by shared ethical passions for and a social imaginary supportive of affirmative alternatives" (Braidotti 2017, p. 47). de Kretser seems to claim in this novella the need to not only erase binary thinking but to go beyond human exceptionalism. To do so, she makes use of ghosts, which could also be defined as not-One due to their lack of tangible corporeality and their complex multiplicity and twists the ghost story's literary pattern subverting both the Vitruvian man and the ghost story genre.

\section{A Ghost Story}

Ghost stories provide alternative imaginaries and, particularly, ways of relating to difference. They allow characters to revisit and negotiate their past, and with it, their present and future, which is not static (Bergson 2004). The past, once reviewed, reveals repressed fears that when voiced within a haunting discourse enables the characters to comprehend-which does not mean solve-their self-doubts. It goes without saying that ghost stories tend to have a close ending, where the mysteries are solved, but this is not the case in Springtime. de Kretser subverts the gothic conventions maintaining the main purpose suggested above, that is, an alternative dialogic voice that functions as a stream of consciousness technique which allows the reader to see the character's soul. In the novella, one of the characters suggests that electricity has put an end to ghost stories and that "people stop seeing ghosts when rooms were properly lit" (Springtime 54). Another character, George Meshaw, considers that it has not to do with the change of lighting but with the way the stories are written: "Ghost stories work up to a shock, but the modern form of the short story is different. When a loose, open kind of story came in, writing about ghosts went out" (Springtime 55). de Kretser shows that other ways of writing a ghost story are possible, that is, they can have an open ending as the one she offers in Springtime. The author combines postmodernist techniques, together with posthuman (Braidotti 2013, 2019) and new materialistic ones (DeLanda 1996; Colebrook 2008; Van der Tuin and Dolphijn 2010), plus she brings light to what used to be a dark gothic atmosphere. The novella's open ending leaves blanks for the reader to fill in —not just the character's enigma, but the readers' constructed reality. Because, not only does de Krester subvert the genre, but, as we will attempt to prove, she also plays with dichotomies, erasing them, in order to provide subjects who do not need an "other" to have a meaning (Derrida [1967] 1998; Foucault [1969] 2002).

Ghost stories are filled with gothic ornament which is usually dark and scarified with wild gardens and violent scenes. David Crouch underlines that "haunted houses provide a precise figure for the unsettled country. Negotiating these anxious architectures and their histories, however, may suggest new possibilities for dwelling in Australia" (Crouch 2007, p. 94). Crouch is referring here to the idea of "terra nullius" as the "founding fantasy of modern Australian nationhood" (Gelder and Jacobs 1998, p. 135-36). That is, the idea of having taken for granted a space to which non-native Australians did not belong provokes an unsettling scenario-“"what is 'ours' may also be 'theirs'" (Gelder and Jacobs 1998, p. 138). This format can be easily represented by a haunting atmosphere. Crouch suggests the need to write Australian spaces as a form of dwelling, which are, according to Paul Carter "living spaces, places where words rebounded, where space itself stood up and spoke ... a total environment of communication: one in which the charge of difference implied the desire to explore, not the stress of ungovernable fear" (Carter 1992, p. 158). Fear represents the uncanny settlement which is the aftermath of the haunting anxiety of not belonging, which as Marie Herbillon points out has "unsurprisingly been reflected in Australian literature" (Herbillon 2018, p. 44). de Kretser has many times written about not belonging (de Kretser [2007] 2008, 2012), but we consider that Springtime does 
not intend to provoke the readers to question if the characters belong or not to Australia. The two main characters, Frances and Charlie, consider themselves natives to Australia although both their mothers are French. De Krester erases the possibility of readers thinking about these characters as inbetweeners by referring to two things they have in common: both their mothers' nationality and them calling a fart a prout (Springtime 5). This ethereal, odorous and finite gas resembles how de Kretser does not want to focus in the present novella on the characters not belonging due to their heritage. A fart is something the people around you can notice for a brief period of time. Following this explanation, we could say that people may know that both Frances and Charlie are not native Australians, but this notion is soon forgotten. This means that they do not need a haunting story for them to dwell since they do belong. In fact, de Kretser does not lucubrate about Frances and Charlie belonging to Australia, but about adjusting to Sydney, as both had lived in Melbourne before. As we can see, de Kretser dislocates the parallelism between a ghost story in Australia and the idea of dwelling, while she breaks with the I-native/Other-non-native dichotomy. The open ending disrupts the classical ghost story pattern plus it reassures the multiple possibilities nowadays of living within fluid trans-spaces where internal and external borders have been resituated, not yet suppressed, by its migrants and diasporans. As George Ritzer highlights, "[g]localization can be defined as the interpretation of the global and the local, resulting in unique outcomes in different geographical areas" (Ritzer 2003, p. 193).

de Kretser plays with the cities of Melbourne and Sydney as if they were two different types of ghost stories-a canonical and a contemporary one. The author offers the reader an alternative view of what a ghost story could be like. Readers do not have to choose between one or the other, as both stories and cities have affirmative characteristics to offer. Readers are given a palimpsest of glocal spaces where, on the one hand, we have Melbourne, described in the novella as more intellectual and sophisticated-as a canonical ghost story would be like (e.g., Marcus Clarke, 1872; Beatrice Grimshaw, 1929; Ernest Favenc, 1988; Mary Fortune, 1867). On the other hand, we have Sydney, aesthetically different from Melbourne, where heat and light may become oppressive, but also where Frances becomes aware of sensual pleasures. That is, Sydney, if compared to contemporary ghost stories, is open to alternative possibilities of becoming. The former, Melbourne, seems to be a somber and dark space while Sydney seems to be a bustling one: "They were serious Melbourne people. They wore stylish dark coats" (Springtime 23); "Sydney didn't do Summer Black" (Springtime 52). At the same time, Melbourne seems fresher and Sydney suffocating: "All her dark clothes had turned a dirty, green-tinged charcoal when pegged out to dry in the Sydney sun" (Springtime 52). Once again, de Krester is twisting dichotomies around and giving city spaces the role of characters with succinct descriptions: "Melbourne's grid, functioned by the straight line and the square" (Springtime 2) while in Sydney "the streets ran everywhere like something spilled" (Springtime 2). Frances is a flâneuse that, together with her dog, Rod, wanders around both spaces. Melbourne represents order, since it is what she already knows so far, while Sydney has a rhizomatic and chaotic effect which makes her wonder about her lost organized past. Melbourne is the place where this 28-year-old character has lived, and it is in Sydney where she can revisit what seemed an ordered epoch. She met Charlie, then a married man and father of Luke, a year before taking a research fellowship on 18th century French portraits at a university in Sydney. As de Kretser herself acknowledges, "the place where you grow up, [it] affects everything about your life" (Watkins 2016) and you will never be free of your past. Frances realizes, once in Sydney, that she is trapped within constructed ideas she has embedded and that is the reason for her seeing ghosts. Together with her dog, Rod, she catches sight of "a woman in the shadowy depths of the garden. She wore a wide hat and trailing pink dress; a white hand emerged from her sleeve" (Springtime 11). Over the weeks, they both saw the woman in the old-fashioned dress (Springtime 21) as if it were a déjà vu (Springtime 13). This phantom reminded her of "something that existed at an angle" (Springtime 21) to her life. It was later revealed that the ghost was Sybil, a mannequin, that allowed her to stop projecting her anxieties into Sydney, her new space, and to accept that they were coming from her romantic relationship with Charlie, as we will further explain. 
de Kretser plays with language, particularly with the words employed for the ghost story's atrezzo, with sentences she displays in italics through the novella as if they were the captions of the portraits she wants to describe. Frances is an art historian, and thus, she is very visual. Readers, due to the descriptions that de Krester offers, are given the opportunity to see the literary depictions as if they were portraits. de Kretser is the creator, Frances is the scholar who studies the 18th-century portraits, and readers become scholars of a 21st-century novella whose role is to understand the drawings of the characters' souls that de Kretser provides. We must bear in mind that those souls belong not only to the human characters but also to the ghosts, dogs and city spaces. The reader becomes not just a mere spectator but an active contrapuntal reader who needs to translate words into images and images into words. For example, the reader can imagine Joseph's face, a friend of Frances and Charlie, thanks to Frances' description: "His face, habitually humorous and alert, was the painter Vernet's face in the portrait by Vigée Le Brun" (Springtime 32). De Krester gives voice to one the of the most important portrait painters of the 18th century, Élisabeth Louise Vigée Le Brun, who is mainly known for depicting the soul of those she painted such as Marie Antoinette. Her style is considered as the aftermath of Rococo, having a color scheme characterized by a soft and airy palette where azure blue, soft pink, white, ivory, cream and gold are the predominant tones. As we can see, de Kretser is using colors that differ from those employed in classic ghost stories. The color palette used by de Krester coincides with those that belong to spring. Both words, ghost and spring, are part of the title of this novella-Springtime. A Ghost Story. De Krester plays with an oxymoron preparing the reader for what he or she is to encounter along the literary work. The garden where both Frances and her dog, Rod, saw the ghost is next to a "path that took them past the river through sports fields and parks" (Springtime 1) where joggers and cyclists greet Frances in the morning. Both Hector, the ghost dog, and Sybil, the ghost mannequin, are in a space that Charlie defines as "creepy" (Springtime 65) because leaves of trees show an overdone trimming, but as Frances highlights "[e]verything looks so normal" (Springtime 65). The ghost is described as "white, silent, and motionless as a tomb" (Springtime 60), which is a pure ghost story description, but the fact that the ghost wears a pink dress differs from the classical ghost. Again, de Krester offers an adjective which alters the classical ghosts' description. If gothic novellas are characterized by winter and darkness, we must bear in mind that Springtime's chronotope (Bakhtin 1981) is set in Sydney, mostly sunny, and during Spring.

A few sentences in italics are carefully placed through the novella and highlighted in italics. They function as subchapters to the literary work, as if they were clues to the theoretical framework employed by de Kretser. At the beginning of the novella Frances types the sentence: "The boundaries of space and time" (Springtime 16), both configurations of the above mentioned chronotope, "that frame human life are neutralized" (Springtime 16). De Krester seems to refer here to Frances becoming conscious of time and space. Both, according to Henri Bergson, are mind-dependent where real time exists merely in our consciousness (Bergson [1911] 2016). As Bergson suggests "For a conscious being to exist is to change, to change is to mature, to mature is to go on creating oneself endlessly" (Bergson [1911] 2016, p. 7). Frances remembers being asleep and Luke waking her up to ask her if she was dead (Springtime 17). This image is followed by a computer-generated female voice, presumably Luke's mother, wishing her "Goodbye" (Springtime 17). This 28-year-old becomes conscious of her age: "I'm not young anymore. How had that happened?" and consciously realizes that life was not a painting where "space was foreshortened, time stilled" (Springtime 11).

\section{A Love Story}

Bearing in mind this process of maturity and leaving aside ghosts, let us focus on one of the main topics of the novella hidden by a ghostly frame. That is love, which is central to this literary work. Frances realizes thanks to the ghost lady she encounters on her walks that discovering Sydney was "a way of exchanging information" (Springtime 25) about Charlie and herself. It is then when she says "I am human and I need love" (Springtime 25). Readers become aware at this point of the importance of the affective turn (Clough and Halley 2007). Affect is in the novella reconceptualized as messy and 
unstable which is far from the order Frances experienced back in Melbourne. Rachel Greenwald Smith highlights how "[p]reconscious feelings and impulses are altered by smells, hormones, gestures and images, and that these affective incitements change depending upon the qualitative conditions of social relations" (Smith Greenwald 2011, p. 423). Frances' dog, Rod, Sydney and ghost Sybil become stimuli that awake Frances' preconscious feelings. Frances' mother was never interested in what Frances thought but in what she felt (Springtime 4). Once Frances is in Sydney, she becomes aware of her real feelings and she understands then what her mother meant. Ghosts, as the narrator suggests, call "for calm and the application" of logic (Springtime 58) urging Frances to consciously reflect on how her thoughts have been constructed, and, with them, her feelings. She needs to tell herself what she thinks and not just what she feels (Springtime 58).

Frances was a solitary and studious girl whose life had taken place in books (Springtime 4). Her life had an order until she moved to Sydney. The ghost lady in pink was like "a ghost from the future that hadn't arrived" (Springtime 25) yet. This image is a prolepsis that adverts Frances that she could be like the mannequin Sybil in a near future. This ghost aids her to realize that this "angel in the house" could be her since it is "Frances's future that contained bars" (Springtime 44). Frances resembles the main character in Doris Lessing's "To Room 19" (1963), trapped within a domestic sphere. She even paints the wall yellow as if she were a character in "The Yellow Wallpaper" (1892) by Charlotte Perkins Gilman. Frances, who saw herself as "irresistible to chivalrous men" (Springtime 42), felt weighed down when Charlie left his marriage to be with Frances for the rest of his life (Springtime 16). Descriptions about Charlie are scattered along the novella and reading them in a consecutive order prove how Frances wanted something else in her life even though she tried to become the angel in the house she was taught to be. Frances realizes that he is old, and so are his friends: "He was fifteen years older than Charlie, which made him thirty years older than Frances-older than her parents" (Springtime 30); "Charlie didn't look ill, only old" (Springtime 35); "She noticed that his teeth were no longer white" (Springtime 59).

The novella also includes four drawings which seem to illustrate Frances love and maturity stages. In the first one, the grass is low and there is a bird; in the second one, the grass is higher and there are two birds; in the third picture, the birds are coupling and the grass is in crescendo; in the fourth and last one, the grass occupies the whole page and there is one bird standing alone. The grass symbolizes Frances' maturity. She does not need anyone but herself to be fulfilled.

\section{Conclusions}

In this novella, de Kretser accommodates Frances' otherness instead of repressing it. Frances tries to occupy both public and domestic spaces, but she feels trapped within the domestic one. When Charlie's son Luke comes to visit, despite her attempt to make cupcakes which not even her dog, Rod, could eat, she feels uncomfortable and she needs to escape, not only from the house but also from her relationship with Charlie. She wants to pursue her dream of studying in Paris where we see her at the end of the novella.

The narrator makes the reader aware of "what people don't pay attention to changes the story" (Springtime 18). This novella seems at first a ghost story, but we are left with the doubt if the ghost is really a ghost. We are told that Sybil is not a ghost but a mannequin, but we do not know if the ghost dog, Hector, whom we know died the summer before Frances saw him, is a ghost. What we do know is that ghosts represent in this novella an ongoing negotiation between the past and the present. They suggest, according to Crouch, "a temporality in which past, present and future can be inter-implicated" (Crouch 2007, p. 95). Frances is in place and out of place simultaneously during her process of identity formation. She is a flâneuse who suggests a dynamic dialogue between herself, her past and her present.

Crouch also suggests the critic "resist the urge to interpret the ghost as a sign of psychological confusion or distress, and instead entertain the real possibility of a spirit world and the consequences of Western culture's attempt to eradicate superstition and all that is deemed unfathomable" (Crouch 2007, 
p. 103). We do not agree with that desire to resist the parallelism between ghosts and psychological confusion, but we comply with the need to incorporate the spirit world because as de Kretser has shown, there is a necessity to decentralize the human subject (Springtime 18). De Kretser's work is, without a doubt, a novella intrinsically connected with feminist thought due to the tradition of enunciating alternative and fluid concepts of home and identities in women's writing.

Funding: This research was funded by the Spanish Ministry of Economy and Competitiveness grant number FFI2016-75130P, "Politics, Aesthetics and Marketing of Literary Formulae in Popular Women's Fiction: History, Exoticism and Romance".

Conflicts of Interest: The author declares no conflict of interest.

\section{References}

Bakhtin, Mikhail. 1981. The Dialogic Imagination. Four Essays. Austin and London: University of Texas Press.

Bergson, Henri. 2016. Creative Evolution. London: Perennial Press. First published 1911.

Bergson, Henri. 2004. Matter and Memory. New York: Dover Publications. First published 1912.

Braidotti, Rosi. 2013. The Posthuman. Boston: Polity Press.

Braidotti, Rosi. 2017. Posthuman, All Too Human. The Memories and Aspirations of a Poshumanist. The 2017 Tanner Lectures Series; New Haven: Yale University, Available online: https://tannerlectures.utah.edu/lecturelibrary.php (accessed on 2 March 2020).

Braidotti, Rosi. 2019. Posthuman Knowledge. Cambridge: Polity Press.

Carter, Paul. 1992. Living in a New Country: History, Travelling and Language. London: Faber \& Faber.

Clough, Patricia, and Jean Halley, eds. 2007. The Affective Turn. Theorizing the Social. Duke: Duke University Press.

Colebrook, Claire. 2008. On Not Becoming Man: The Materialist Politics of Unactualized Potential. In Material Feminisms. Edited by Stacy Alaimo and Susan Hekman. Indianapolis: Indiana University Press, pp. 52-84.

Crouch, David. 2007. National Hauntings: The Architecture of Australian Ghost Stories. Journal of the Association for the Study of Australian Literature. Available online: https://openjournals.library.sydney.edu.au/index.php/ JASAL/article/view/9642 (accessed on 10 March 2020).

de Kretser, Michelle. 2008. The Lost Dog. Crows Nest: Allen \& Unwin. First published 2007.

de Kretser, Michelle. 2012. Questions of Travel. Crows Nest: Allen \& Unwin.

de Kretser, Michelle. 2014. Springtime. A Ghost Story. New York: Catapult.

DeLanda, Manuel. 1996. The Geology of Morals: A Neo-Materialist Interpretation. Available online: http: //www.t0.or.at/delanda/geology.htm (accessed on 15 February 2020).

Derrida, Jacques. 1998. Of Grammatology. Baltimore and London: The Johns Hopkins University Press. First published 1967.

Foucault, Michel. 2002. Archaeology of Knowledge. New York: Routledge. First published 1969.

Gelder, Ken, and Jane M. Jacobs. 1998. Uncanny Australia: Sacredness and Identity in a Postcolonial Nation. Melbourne: Melbourne UP.

Herbillon, Marie. 2018. Absent Others: Asian-Australian Discontinuities in Michelle de Kretser's The Lost Dog. Commonwealth Essays and Studies 41: 43-52. [CrossRef]

Ritzer, George. 2003. Rethinking globalization: Glocalization/Grobalization and Something/Nothing. Sociological Theory 21: 193-209. [CrossRef]

Smith Greenwald, Rachel. 2011. Postmodernism and the Affective Turn. Twentieth Century Literature 57: 423-46. [CrossRef]

Van der Tuin, Iris, and Rick Dolphijn. 2010. The Transversality of New Materialism. Women: A Cultural Review 21: 153-71. [CrossRef] 
Van Loon, Julienne. 2019. The Thinking Woman. Randwick: University of New South Wales Press.

Watkins, Alexandra. 2016. Alexandra Watkins Interviews Michelle de Kretser on 'Springtime'. Mascara Literary Review. Available online: http://mascarareview.com/alexandra-watkins-interviews-michelle-de-kretserabout-springtime-a-ghost-story/ (accessed on 10 March 2020). 